\title{
Mineral digestibility of different animal sources for the silver catfish Rhamdia voulezi
}

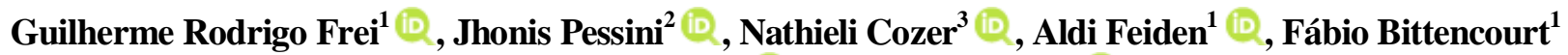 \\ Wilson Boscolo ${ }^{1}$ \& Altevir Signor ${ }^{1}$ \\ ${ }^{1}$ Grupo de Estudos de Manejo na Aquicultura, Universidade Estadual do Oeste do Paraná (UNIOESTE) \\ Toledo, Paraná, Brasil \\ ${ }^{2}$ Laboratório de Nutrição de Espécies Aquícolas, Universidade Federal de Santa Catarina (UFSC) \\ Florianópolis, Santa Catarina, Brasil \\ ${ }^{3}$ Grupo Integrado de Aquicultura e Estudos Ambientais, Universidade Federal do Paraná (GIA) \\ Curitiba, Paraná, Brasil \\ Corresponding author: Jhonis Pessini (jhonispessini@ hotmail.com)
}

\begin{abstract}
This study aimed to evaluate the apparent digestibility coefficients (ADCs) of dry matter, crude protein, gross energy, and minerals of marine fish meal (MFM), salmon meal (SM), tilapia by-product meal (TBM), meat and bone meal (MBM), poultry by-product meal (PBM), blood meal (BM), and feather meal (FM) by silver catfish Rhamdia voulezi. Groups of 12 fish were fed the experimental diet three times a day until apparent satiation, and the fecal samples were collected from an accumulation device. SM and PBM exhibited the highest digestibility values for dry matter, crude protein, and gross energy, while MBM and FM presented significantly lower ADCs for dry matter. BM and FM exhibited higher ADCs for phosphorus, 65.05 and 63.87\%, respectively. The ADCs for calcium were $58.8 \%$ for MFM, 56.69\% for TBM, and $60.08 \%$ for PBM. PBM and FM had the highest iron ADCs, 44.01 and 46.29\%, respectively. Magnesium ADCs ranged from 44.87\% for MBM to $75.50 \%$ for TBM. BM had the highest digestibility for zinc $(62.77 \%)$, whereas MBM $(36.68 \%)$ and FM $(39.39 \%)$ had the lowest. In general, SM and PBM showed higher values as feedstuffs for silver catfish feeds. At the same time, the digestibility was lower for TBM and MBM for macronutrients and minerals such as phosphorus, iron, and zinc.
\end{abstract}

Keywords: Rhamdia voulezi; fish nutrition; macrominerals; microminerals; phosphorus; aquaculture

\section{INTRODUCTION}

Minerals are essential nutrients for fish because they have important functions in different pathways in their metabolism (Araújo et al. 2018). The minerals, classified as macrominerals, are required in higher quantities, and microminerals, required in minimum quantities. Among the macrominerals, calcium $(\mathrm{Ca})$, phosphorus $(\mathrm{P})$, and magnesium $(\mathrm{Mg})$ are essential for bone development, regulation of intracellular homeostasis, and cofactors for several metabolic enzymes (Bakke et al. 2010, Suttle 2010). Among the microminerals, iron
$(\mathrm{Fe})$ is a major constituent of proteins, including hemoglobin and myoglobin, which participate in the transport of mitochondrial electrons and are crucial for the proper function of the immune system and cellular respiration (Kwong et al. 2013, Zhang et al. 2016, Luo et al. 2017). Likewise, zinc (Zn) is important for cell proliferation, the immune system and plays a major role against free radicals (Kumar et al. 2017).

In this context, studies on the digestibility of minerals from different sources are essential to understand the nutritional quality of these ingredients better. The appropriate inclusion of mineral levels in

Corresponding editor: Mariel Gullian 
fish diets can prevent a macrominerals interaction, such as $\mathrm{Ca}$ and $\mathrm{P}$, with other minerals present in the gastrointestinal tract (Lall 2002, Guimarães et al. 2012). It also reduces the excessive discharge of $P$, a major nutrient responsible for eutrophi-cation in water bodies (Bock et al. 2007). Furthermore, the correct balance of minerals in the diet reduces the need to include inorganic sources of minerals, which have low bioavailability than organic sources and may make it possible to formulate economic and environmentally safe diets.

Because of the morphological differences of the digestive systems of fish species, the digestibility values of available minerals vary among different ingredients (Araújo et al. 2018). However, few studies compare mineral digestibility between species (Sugiura et al. 1998a, Sugiura et al. 2006). The silver catfish, Rhamdia voulezi, is an emergent species in aquaculture and has a huge potential for creation in cold tropical areas (Pedron et al. 2008). This fish presents zootechnical characteristics favorable for production and reproduction in these areas. Also, it has intramuscular bone-free meat and good market value (Baldisserotto \& Radunz 2005). However, there is little information available on nutrition and feed for an accurate formulation of diets for this species that maximizes its growth performance.

Although several studies evaluating the digestibility of different sources of ingredients have recently been run (Oliveira-Filho \& Fracalossi 2006, Signor et al. 2016, Lewandowski et al. 2017, Friesa et al. 2020), no studies are evaluating the mineral digestibility in animal by-products meal. Thus, to improve information on digestibility and enhancement of diet formulations, this study aimed to evaluate the digestibility of minerals, dry matter, crude protein, and gross energy of marine fish meal, salmon meal, tilapia by-product meal, meat and bone meal, poultry by-product meal, blood meal, and feather meal for silver catfish.

\section{MATERIALS AND METHODS}

\section{Experimental diets and ingredients}

Seven tested animal feed sources were compounded in the experimental diets. Diets consisted of $30 \%$ of the tested ingredient, $69.8 \%$ of the dietary reference, and $0.2 \%$ of the inert chromium oxide marker. For the formulation of the reference diet, practical ingredients were used to meet the nutritional requirements for silver catfish Rhamdia voulezi (Freitas et al. 2011). The other nutrients are formulated based on the channel catfish Ictalurus punctatus requirement (NRC 2011) as recommended by Radunz-Neto \& Borba (2013) (Table $1)$.
Table 1. Formulation and composition of the reference diet. ${ }^{1}$ Guaranteed levels per kilogram of product: Vit. A, 1,750,000 UI; Vit. D3, 375,000 UI; Vit. E, 20,000 UI; Vit. K3, $500 \mathrm{mg}$; Vit. B1, $2000 \mathrm{mg}$; Vit. B2, $2500 \mathrm{mg}$; Vit. B6, $2500 \mathrm{mg}$; Vit. B12, $5000 \mathrm{mg}$; folic acid, $625 \mathrm{mg}$; pantothenate calcium, $7500 \mathrm{mg}$; Vit. C, 37,500 mg; biotin, $50 \mathrm{mg}$; inositol, $12,500 \mathrm{mg}$; niacin, $8750 \mathrm{mg}$; colin, 100,000 mg; Co, $50 \mathrm{mg}$; Cu, $1250 \mathrm{mg}$; Fe, 15,000 mg; iodine, $100 \mathrm{mg}$; manganese, $3750 \mathrm{mg}$; selenium, $75 \mathrm{mg}$; zinc, $17,500 \mathrm{mg}$.

\begin{tabular}{lr}
\hline Ingredients & $\mathrm{g} \mathrm{kg}^{-1}$ \\
\hline Soybean meal & 489.20 \\
Corn & 221.90 \\
Broken rice meal & 150.10 \\
Fish meal & 20.00 \\
Poultry by-product meal & 30.00 \\
Soybean oil & 29.10 \\
Vitamin and mineral Premix & 10.00 \\
Limestone & 9.00 \\
Salt & 3.00 \\
Antifungal & 1.00 \\
Antioxidant & 2.00 \\
Chromium oxide & 2.00 \\
\hline Centesimal composition $\left(\mathrm{g} \mathrm{kg}^{-1}\right)$ of dry matter \\
\hline Dry matter & 919.10 \\
Crude protein & 315.80 \\
Gross energy $\left(\mathrm{kcal} \mathrm{kg}^{-1}\right)$ & 4189.50 \\
Ethereal extract & 39.70 \\
Ash & 73.20 \\
\hline
\end{tabular}

The test ingredients were the marine fish meal (MFM), poultry by-product meal (PBM), tilapia byproduct meal (TBM), salmon meal (SM), meat and bone meal (MBM), feather meal (FM), and blood meal $(\mathrm{BM})$. The test ingredients had their proximate compositions analyzed, which are summarized in Table 2 . The ingredients were used in the reference diet. Each was ground and passed through a $0.5 \mathrm{~mm}$ sieve, weighed, manually mixed, and extruded in a model extruder Ex-Laboratório (EXTEEC, Ribeirão Preto, Brazil). The extrusion parameters were as follows: temperature, $100^{\circ} \mathrm{C}$; thread speed, $200 \mathrm{rpm}$; flow rate, $40 \%$ of rated capacity; thread diameter, $30 \mathrm{~mm}$; and cylinder length, $100 \mathrm{~mm}$. The inert marker, chromium oxide, was added to the diets during the homogenization of the ingredients.

\section{Animals and experimental design}

Groups of 12 silver catfish with an initial mean weight of $285 \pm 44.02 \mathrm{~g}$ and an initial mean length of $30.28 \pm$ $1.96 \mathrm{~cm}$ were kept in experimental units with cylindrical-conics shape (500 L useful volume). The experimental units were connected to a water recirculation system (RAS), equipped with mechanical-bio- 
Table 2. Proximate composition of the ingredients tested \% dry matter. Ingredients provided by BRF-Brazil Foods/ToledoPR. MFM: marine fish meal, SM: salmon meal, TBM: tilapia by-product meal, MBM: meat and bone meal, PBM: poultry by-product meal, BM: bone meal, FM: feather meal.

\begin{tabular}{lrrrrrrr}
\hline & \multicolumn{7}{c}{ Ingredients $\left(\mathrm{g} \mathrm{kg}^{-1}\right)$} \\
\cline { 2 - 8 } & MFM & SM & TBM & MBM & PBM & BM & FM \\
\hline Dry matter & 922.70 & 904.00 & 942.70 & 940.40 & 928.30 & 940.40 & 929.70 \\
Crude protein & 584.90 & 724.30 & 554.50 & 479.50 & 583.10 & 858.10 & 857.20 \\
Gross energy $\left(\mathrm{kcal} \mathrm{kg}^{-1}\right)$ & 4083.00 & 4334.00 & 5090.00 & 4034.00 & 4923.00 & 3791.00 & 5232.00 \\
Lipid & 118.60 & 96.10 & 112.10 & 170.10 & 187.40 & 120.50 & 46.40 \\
Ash & 254.30 & 172.50 & 297.10 & 281.60 & 159.80 & 2950 & 25.70 \\
\hline Phosphorus & 42.40 & 30.20 & 44.10 & 64.40 & 41.50 & 6.90 & 6.60 \\
Calcium & 88.00 & 60.03 & 114.90 & 115.50 & 79.60 & 19.70 & 15.40 \\
Magnesium & 4.80 & 3.10 & 3.30 & 4.20 & 2.70 & 1.30 & 1.10 \\
Iron & 2.93 & 0.06 & 0.33 & 1.00 & 0.62 & 0.22 & 0.45 \\
Zinc & 0.42 & 0.61 & 0.28 & 0.28 & 0.34 & 0.71 & 0.31 \\
\hline
\end{tabular}

logical filtration, temperature control, and constant aeration via a thermostat and air blower. A completely randomized design was adopted, consisting of eight treatments (seven test ingredients + reference diet) and three replicates, totaling 24 experimental units.

\section{Experimental procedure}

Before the digestibility trial, fish were acclimatized and fed with the reference diet for seven days in experimental units, equipped with a $50 \mathrm{~mL}$ tube on the bottom for feces collection. After this process, fish were also acclimatized to the experimental diets for seven days. During the acclimatization process and the digestibility trial, fish were fed the experimental diets three times a day $(11: 00,14: 00$, and 18:00 h) until apparent satiation. Feces sampling was performed daily at 07:00 h for 70 days. After the feces collection, samples were stored in a freezer at $-20^{\circ} \mathrm{C}$ for further analysis. At the end of sample collection, each treatment sample was pooled and dried in a forced ventilation oven at $55^{\circ} \mathrm{C}$ for $72 \mathrm{~h}$ and then analyzed.

\section{Analyses of chemical composition}

Analyses of the chemical composition of the reference diet tested ingredients and feces were performed according to the method of AOAC (1999). Dry matter (dried in an oven at $105^{\circ} \mathrm{C}$, method 950.01), ethereal extract by Soxhlet (method 920.39C), crude protein by the Kjeldahl method (method 945.01), ashes by incineration in a muffle at $550^{\circ} \mathrm{C}(\operatorname{method} 942.05)$, and energy (Calorimetric Pump - IKA Basic, 2000). For the chromium oxide analyses of diets and feces, the methodology followed Bremer-Neto et al. (2003).

\section{Mineral analysis}

The concentration of phosphorus in feces and experimental diets was determined by the colorimetric method, using vanado molybdate as a reagent, according to the methodology described by AOAC (1999). $\mathrm{Ca}, \mathrm{Mg}, \mathrm{Fe}$ and $\mathrm{Zn}$ were determined by nitroperchloric digestion and quantified using flame absorption spectrometry (FAAS) (Cookbook Shimadzy 2002) manufacturer's instructions.

\section{Apparent digestibility coefficients}

The results obtained from feces and diet analyses were used to calculate the apparent digestibility coefficients (ADC) of the diets and ingredients, respectively, as described by Bureau et al. (1999), as follows:

$$
A D C(\%)=100-\left\{100 x\left[\left(\frac{\% \text { Indicator } D}{\% \text { Indicator } F}\right) x\left(\frac{N F}{N D}\right)\right]\right\}
$$

where $\%$ indicator $\mathrm{D}$ : percentage of the indicator present in the diet; \% indicator F: percentage of the indicator present in the feces; NF: amount of nutrient present in feces; and ND: amount of nutrients presents in the diet.

Subsequently, calculations of the digestibility coefficients of the ingredients were performed using the following formula:

$$
A D C_{i n g}=\frac{\left(D C_{(t d)}-b \times D C_{(r d)}\right)}{a}
$$

where $\mathrm{ADC}_{\mathrm{ing}}$ : coefficient of digestibility of the ingredients; $\mathrm{DC}_{(\mathrm{td})}$ : coefficient of digestibility of the test diet; $\mathrm{DC}_{(\mathrm{rf})}$ : coefficient of digestibility of the reference diet; $b$ : percentage of the reference diet; and a: percentage of test ingredient. 


\section{Water quality parameters}

The experimental units were cleaned once a day (7:30 h), with a $50 \%$ water renewal of the volume water from a water well to remove suspended metabolites. The water quality parameters, including temperature (24.30 $\left.\pm 1.2^{\circ} \mathrm{C}\right)$ and dissolved oxygen $\left(5.23 \pm 0.50 \mathrm{mg} \mathrm{L}^{-1}\right)$, were measured daily before tank cleaning. The $\mathrm{pH}$ $(7.88 \pm 0.5)$ and electrical conductivity $(13.68 \pm 0.12$ $\mu \mathrm{S} \mathrm{cm}^{-1}$ ) were measured weekly. The photoperiod during the experimental period was adjusted to $12 \mathrm{~h}$ light and $12 \mathrm{~h}$ dark. The values of water quality parameters remained within that recommended species (Maffezzolli \& De Oliveira-Nuner 2006, Piedras et al. 2018).

\section{Statistical analyses}

The results obtained were subjected to normality analysis by the Shapiro-Wilk test and homoscedasticity by the Levene test. Given these assumptions, the data were analyzed by one-way analysis of variance (ANOVA). When there was a significant difference, Tukey's test was performed for the comparison of means. Besides, a correlation analysis (Pearson's test) was carried out between the ashes of the ingredients and minerals of the test diets with the ADCs of the evaluated minerals. The significance level adopted was $5 \%$ for all tests and was performed with the statistical software Statistica 7.0 (StatSoft Inc., Tulsa, USA).

\section{RESULTS}

\section{Apparent digestibility coefficients of dry matter, crude protein, and gross energy}

The digestibility coefficients for dry matter, crude protein, and crude energy are shown (Table 3). The salmon meal, for dry matter, had the highest digestibility coefficient, $83.52 \%$. On the other hand, the meat and bone meal and feather meal had the lowest digestibility coefficients, 48.08 and $50.83 \%$. Regarding protein digestibility, salmon meal and poultry byproduct meal exhibited higher digestibility coefficients, 93.87 and $93.04 \%$, respectively, and the tilapia byproduct meal and meat and the bone meal had the lowest digestibility coefficients for this nutrient, 72.59 and $78.27 \%$, respectively. The values ranged from 61.00 to $91.49 \%$ for gross energy, in which the salmon meal presented the highest digestibility coefficient value and meat, and the bone meal had the lowest.

\section{Apparent digestibility coefficients of minerals}

The digestibility coefficients for $\mathrm{P}, \mathrm{Ca}, \mathrm{Fe}, \mathrm{Mg}$, and $\mathrm{Zn}$ were statistically different for the tested ingredients $(P<0.05)$ (Table 4$)$. The highest digestibility coeffi- cients were observed for the blood meal and feather meal, 65.05 and $63.97 \%$. The lowest coefficients were observed for the tilapia by-product meal and meat and bone meal, 47.44 and $47.36 \%$, respectively. Regarding $\mathrm{Ca}, \mathrm{MFM}$, TBM, and PBM had the highest digestibility coefficients, 58.80, 56.69, and $60.08 \%$, respectively. On the other hand, the lowest digestibility coefficient was exhibited by feather meal, 45.21\%. ACD-Fe ranged from 46.29 to $15.67 \%$, with poultry by-product meal and feather meal showing the highest values and the meat and bone meal exhibiting the lowest value for digestibility of this mineral. The digestibility coefficients varied from $75.5 \%$ for the TBM to $44.87 \%$ for MBM for Mg. The BM had the highest digestibility coefficient for $\mathrm{Zn}, 62.77 \%$, and the TBM had the lowest, $23.11 \%$.

\section{Correlation coefficients}

The correlation coefficients are summarized in Table 5. There was a negative correlation between ash content and ADC-P (-0.97), ADC-Fe (-0.63), and ADC-Zn (-0.66). $\mathrm{P}$ also resulted in a negative correlation between the ADC-P (-0.91) and ADC-Fe (-0.74). Ca showed a negative correlation with the ADC-P -0.99), $\mathrm{ADC}-\mathrm{Fe}(-0.64) \mathrm{ADC}-\mathrm{Zn}(-0.63)$. For $\mathrm{Mg}$, there was a negative correlation between ADC-P (-0.84) and ADC$\mathrm{Fe}(-0.63)$. Zn showed a positive correlation for ADC$\mathrm{Zn}$ (0.77). Besides that, the other possible correlations did not show significant differences $(P>0.05)$.

\section{DISCUSSION}

\section{Nutrient and energy digestibility}

Among the tested ingredients, the most used in fish diets in the MFM is its excellent palatability and amino acid balance (Kaushik \& Seiliez 2010, Liu et al. 2012). However, there is huge global fishing pressure on forage species. It has caused the depreciation of the natural stock (FAO 2018), increasing its price and making the fish feed more expensive. This ingredient had intermediate ADC values for the tested nutrients and energy compared to those of the other tested ingredients for silver catfish. Further, the results from this study corroborate the results obtained by OliveiraFilho \& Fracalossi (2006), who evaluated the digestibility of FM for silver catfish, Rhamdia quelen, and found values of $70.3,85$, and $77 \%$ for dry matter, protein, and gross energy, respectively.

The highest ADCs for dry matter and crude protein were observed for the SM and PBM meal, suggesting a high biological value of these ingredients for the target species of this study. However, it is important to note 
Table 3. Apparent digestibility coefficients (\%) for dry matter (DM), crude protein (CP) and gross energy (GE), and digestible values of protein $\left(\mathrm{g} \mathrm{kg}^{-1}\right.$ - DP) and energy ( $\mathrm{kcal} \mathrm{kg}^{-1}$ - DE) for silver catfish, Rhamdia voulezi. Values are means of triplicate groups \pm standard error mean. Means followed by different superscript letters in the same column differ according to Tukey's test $(P<0.05)$.

\begin{tabular}{lccccc}
\hline Ingredients & DM & CP & GE & DP & DE \\
\hline Reference diet & $85.39 \pm 0.29$ & $93.52 \pm 0.05$ & $88.95 \pm 0.12$ & - & - \\
Marine fish meal & $63.01 \pm 0.29^{\mathrm{c}}$ & $84.79 \pm 0.96^{\mathrm{b}}$ & $77.93 \pm 0.47^{\mathrm{b}}$ & 49.59 & 3181.88 \\
Salmon meal & $83.52 \pm 1.25^{\mathrm{a}}$ & $93.87 \pm 0.64^{\mathrm{a}}$ & $91.49 \pm 1.13^{\mathrm{a}}$ & 67.99 & 3965.17 \\
Tilapia by-product meal & $64.11 \pm 0.24^{\mathrm{c}}$ & $72.59 \pm 0.25^{\mathrm{d}}$ & $65.53 \pm 1.10^{\mathrm{c}}$ & 40.25 & 3335.47 \\
Meat and bone meal & $48.08 \pm 0.66^{\mathrm{d}}$ & $78.27 \pm 0.68^{\mathrm{c}}$ & $61.00 \pm 0.46^{\mathrm{c}}$ & 37.53 & 2460.74 \\
Poultry by-product meal & $77.18 \pm 0.04^{\mathrm{b}}$ & $93.04 \pm 0.19^{\mathrm{a}}$ & $87.34 \pm 0.68^{\mathrm{a}}$ & 54.25 & 4299.74 \\
Blood meal & $75.07 \pm 0.46^{\mathrm{b}}$ & $84.86 \pm 0.49^{\mathrm{b}}$ & $74.66 \pm 0.57^{\mathrm{b}}$ & 72.81 & 2830.38 \\
Feather meal & $50.83 \pm 0.66^{\mathrm{d}}$ & $82.99 \pm 0.17^{\mathrm{b}}$ & $76.19 \pm 1.83^{\mathrm{b}}$ & 71.13 & 3986.26 \\
\hline
\end{tabular}

Table 4. Apparent digestibility coefficients (\%) of phosphorus, calcium, magnesium, iron, and zinc for marine fish meal, salmon meal, tilapia by-product meal, meat and bone meal, poultry by-product meal, blood meal, and feather meal for silver catfish, Rhamdia voulezi. Values are means of triplicate groups \pm standard error mean. Means followed by different superscript letters in the same column differ according to Tukey's test $(P<0.05)$.

\begin{tabular}{lccccc}
\hline Ingredients & Phosphorus & \multicolumn{1}{c}{ Calcium } & \multicolumn{1}{c}{ Magnesium } & Iron & Zinc \\
\hline Marine fish meal & $51.99 \pm 2.35^{\mathrm{bc}}$ & $58.80 \pm 28.44^{\mathrm{a}}$ & $49.83 \pm 4.92^{\mathrm{cd}}$ & $35.78 \pm 3.79^{\mathrm{b}}$ & $44.27 \pm 1.77^{\mathrm{bc}}$ \\
Salmon meal & $58.39 \pm 4.79^{\mathrm{ab}}$ & $52.67 \pm 5.81^{\mathrm{ab}}$ & $65.52 \pm 2.25^{\mathrm{b}}$ & $33.07 \pm 10.56^{\mathrm{b}}$ & $45.87 \pm 1.02^{\mathrm{bc}}$ \\
Tilapia by-product meal & $47.44 \pm 0.05^{\mathrm{c}}$ & $56.69 \pm 22.46^{\mathrm{a}}$ & $75.50 \pm 2.16^{\mathrm{a}}$ & $34.74 \pm 6.05^{\mathrm{b}}$ & $23.11 \pm 3.64^{\mathrm{d}}$ \\
Meat and bone meal & $47.36 \pm 0.93^{\mathrm{c}}$ & $52.47 \pm 11.13^{\mathrm{ab}}$ & $44.87 \pm 3.71^{\mathrm{d}}$ & $15.67 \pm 8.22^{\mathrm{c}}$ & $36.68 \pm 1.10^{\mathrm{c}}$ \\
Poultry by-product meal & $55.71 \pm 0.68^{\mathrm{b}}$ & $60.08 \pm 8.71^{\mathrm{a}}$ & $64.42 \pm 3.01^{\mathrm{b}}$ & $44.01 \pm 33.11^{\mathrm{a}}$ & $50.22 \pm 4.67^{\mathrm{b}}$ \\
Blood meal & $65.05 \pm 2.93^{\mathrm{a}}$ & $53.85 \pm 10.52^{\mathrm{ab}}$ & $56.40 \pm 10.08^{\mathrm{c}}$ & $38.68 \pm 7.16^{\mathrm{ab}}$ & $62.77 \pm 1.02^{\mathrm{a}}$ \\
Feather meal & $63.97 \pm 6.06^{\mathrm{a}}$ & $45.21 \pm 21.58^{\mathrm{b}}$ & $52.23 \pm 13.29^{\mathrm{c}}$ & $46.29 \pm 6.56^{\mathrm{a}}$ & $39.39 \pm 7.66^{\mathrm{c}}$ \\
\hline
\end{tabular}

Table 5. Correlation coefficients between mineral apparent digestibility coefficients (ADCs), ash and minerals content in tested ingredients for silver catfish, Rhamdia voulezi. "Significant values $(P<0.05)$, ns: non-significant values, $\mathrm{P}$ : phosphorus, Ca: calcium, Mg: magnesium, Fe: iron, Zn: zinc.

\begin{tabular}{lccccc}
\hline \multirow{2}{*}{ Nutrient } & \multicolumn{5}{c}{ ADC } \\
\cline { 2 - 6 } & ADC-P & ADC-Ca & ADC-Mg & ADC-Fe & ADC-Zn \\
\hline Ash & $-0.97^{*}$ & ns & Ns & $-0.63^{*}$ & $-0.66^{*}$ \\
$\mathrm{P}$ & $-0.91^{*}$ & ns & Ns & $-0.74^{*}$ & ns \\
$\mathrm{Ca}$ & $-0.99^{*}$ & $\mathrm{~ns}$ & $\mathrm{Ns}$ & $-0.64^{*}$ & $-0.63^{*}$ \\
$\mathrm{Mg}$ & $-0.84^{*}$ & $\mathrm{~ns}$ & $\mathrm{Ns}$ & $-0.63^{*}$ & $\mathrm{~ns}$ \\
$\mathrm{Fe}$ & $\mathrm{ns}$ & $\mathrm{ns}$ & $\mathrm{Ns}$ & $\mathrm{ns}$ & $\mathrm{ns}$ \\
$\mathrm{Zn}$ & $\mathrm{ns}$ & $\mathrm{ns}$ & $\mathrm{Ns}$ & $\mathrm{ns}$ & $0.77^{*}$ \\
\hline
\end{tabular}

that SM is not available as a PBM and having a higher price, making PBM a better target ingredient for the silver catfish diets. The present study results corroborate those found by Kitagima \& Fracalossi (2011), who evaluated the apparent diges-tibility of animal source ingredients for channel catfish. The ADC values for gross energy and crude protein were above $90 \%$, and that of dry matter was above $70 \%$ for PBM.

On the other hand, MBM exhibited the worst ADCs for dry matter (48.08\%) and crude protein $(78.27 \%)$. It is possible that the high mineral content $(28.16 \%)$ negatively influenced nutrient digestibility (Pastore et al. 2013). The former was also shown by Kitagima \& Fracalossi (2011) in a study on channel catfish, wherein they tested the digestibility of shrimp meal containing high mineral content $(42 \%)$. FM also had a low ADC for dry matter, at $50.83 \%$; however, it has a low mineral matter content $(2.57 \%)$. The low digestibility presented by the FM may be related to its long processing of chicken feather hydrolysis under high temperature and pressure, leading to a low digestibility (Moritz \& Latshaw 2001). Besides, proteins derived from feathers are not well digested as muscle proteins (NRC 1993). 
Similarly, Pezzato et al. (2002) evaluated the digestibility of five animal source ingredients for Nile tilapia, Oreochromis niloticus. They found that the worst dry matter digestibility results were attained for FM. Furthermore, the dry matter digestibility coefficient was lower than those found $(37.39 \%)$ in the present study (50.83\%), probably related to the quality difference between the FM tested in the studies.

In contrast to our results, Boscolo et al. (2008) evaluated TBM ADCs for Nile tilapia and obtained higher values for dry matter $(83.55 \%)$, protein $(88.13 \%)$, and gross energy $(84.74 \%)$. These differences are probably related to the composition of meals: in the present study, TBM had a higher ash content (29.71-18.75\%) than in the study by Boscolo et al. (2008), and high ash content are known to impair de digestibility of others nutrients, especially proteins (Pastore et al. 2013, Silva et al. 2013). In addition, the FM can be classified as first quality, with protein levels above $60 \%$, and second quality, with protein level approximately 50\% (Boscolo et al. 2008), as is the case with TBM used in the present study.

A factor that may have contributed to the low digestibility of some sources tested is related to the high ash value in its composition, evidenced mainly for MBM and TBM, as observed in other studies with these ingredients (Pezzato et al. 2002, Furuya et al. 2008). In addition, FM, due to its processing and low biological value, also presented, in general, low digestibility, as previously mentioned.

\section{Mineral digestibility coefficients}

Mineral digestibility of the ingredients is poorly understood for fish, and few studies evaluate these compounds (Araújo et al. 2018, Radunz-Neto \& Borba 2013). For silver catfish Rhamdia voulezi, the species in this study, the mineral requirements are not known; therefore, it is recommended by Radunz-Neto \& Borba (2013) to use the requirements presented for channel catfish Ictalurus punctatus NRC (2011). Phosphorus is the most limiting mineral in fish diet formulations, especially in plant-based diets. When incorporating animal by-products, such as MFM and MBM, it is common to exceed fish $\mathrm{P}$ requirements since these ingredients usually contain the highest ash concentrations (Furuya et al. 2008). Thus, the highest phosphorus digestibility was observed for FM and BM, ingredients with low mineral content, 0.64 and $0.37 \%$, respectively. It is important to note that SM and PBM had higher digestible $\mathrm{P}$ values when compared to MFM, TBM, and MBM.

On the other hand, the lowest ADC-P values were verified for MBM and TBM, ingredients with higher $P$ content, 6.44 and $4.34 \%$, respectively. Accordingly to
Rodehutscord et al. (2000), the minerals digestibility, especially $\mathrm{P}$, depended on their concentration in the ingredient source. This hypothesis is supported by a high negative correlation (-0.97) between the ash amount of the ADC-P and P and ADC (-0.91). Our results suggest that one should limit the inclusion of the ingredient with high mineral concentrations in silver catfish diets because of its low $\mathrm{P}$ digestibility and its excretion in the environment, which is undesirable because it is a major eutrophic agent (Diemer et al. 2014).

Moreover, diets with high $\mathrm{P}$ content negatively affect $\mathrm{Mg}$ absorption (Schamber et al. 2014). This negative effect may be related to the physiological saturation of the $\mathrm{Ca}$ and $\mathrm{P}$ transporter in the brush border membrane, leading to an excess of these minerals in the form of insoluble complexes in the digestive tract lumen, thereby reducing $\mathrm{Mg}$ absorption (Nwanna et al. 2009, Araújo et al. 2018). In the present study, $\mathrm{Mg}$ absorption ranged from 44.87 to $75.50 \%$. The lowest $\mathrm{Mg}$ digestibility was verified for MBM, $44.87 \%$, which had a higher P content, $6.44 \%$, relative to other tested ingredients; thus, supporting this hypothesis.

$\mathrm{Ca}$ requirements by fish are largely met by absorption from the aquatic environment through the gills (De Miranda et al. 2000), with the gut being a site of poor absorption for this mineral (Lall 2002). In addition, it is common for $\mathrm{Ca}$ digestibility studies to confuse results because of the ability of $\mathrm{Ca}$ to be absorbed from the water by fish (Bock et al. 2007, Lewandowski et al. 2017). ADC values for relatively high $\mathrm{Ca}$ were observed in different ingredients tested, ranging from 45 to $60 \%$. These results may indicate that the recirculation system did not contain high $\mathrm{Ca}$ values, making it necessary for fish to use dietary $\mathrm{Ca}$ to meet their nutritional requirements.

$\mathrm{Fe}$ and $\mathrm{Zn}$ digestibility was lower than $51 \%$ over the tested treatments, except for FM and BM, corroborating results found by Araújo et al. (2018) about low digestibility for microminerals in animal ingredients with high ash concentration. Also, there was a negative correlation between the amount of ash in the ingredients with the ADC-Fe (-0.63) and ADC-Zn ($0.66)$. Similar results have been reported for rainbow trout (Oncorhynchus mykiss) and coho salmon (Oncorhynchus kisutch), where low digestibility of these minerals was observed in six different animal ingredients (Sugiura et al. 1998a,b). The authors suggested that the high content of $\mathrm{Ca}$ and $\mathrm{P}$ in the ingredients also negatively affected $\mathrm{Fe}$ and $\mathrm{Zn}$ absorption. Similar results were also found in the present study. The $\mathrm{P}$ and $\mathrm{Ca}$ content showed a negative correlation with ADC-Fe, -0.64 and -0.74 , respectively. 
Also, $\mathrm{Ca}$ content resulted in a negative correlation with ADC-Zn (-0.66).

\section{CONCLUSION}

In this study, silver catfish presented better macronutrient ADCs values for the SM and PBM, suggesting a high value of these ingredients in diets for $R$. voulezi. On the other hand, lower digestible values for these variables were found for MBM and TBM and the minerals $\mathrm{P}, \mathrm{Fe}$, and $\mathrm{Zn}$ indicating a low value of these ingredients in diets for silver catfish. The digestibility of minerals was unclear, and it is not possible to observe an obvious trend among the tested ingredients.

\section{ACKNOWLEDGMENTS}

This work was supported by Chamada Pública MCTI/CNPq/MEC/Capes Ação Transversal \#06/2011

- Casadinho/Procad PROCESSO \#552224/2011-5; Chamada Pública 23/2012 Programa de Apoio a Núcleos Emergentes - Pronem (Acordo CNPq/FA) Convênio \#821/2013 and was financed in part by the Coordenação de Aperfeiçoamento de Pessoal de Nível Superior - Brasil (CAPES) Finance Code 001. We also thank to Douglas Ismael Cadorin to writing assistance.

\section{REFERENCES}

Araújo, J.G., Nebo, C., Pádua, D.M., Souto, C.N. \& Guimarães, I.G. 2018. Apparent digestibility of minerals from several ingredients for Tambaqui, Colossoma macropomum, juveniles. Journal of the World Aquaculture Society, 49: 1026-1038. doi: 10.1111/jwas. 12517

Association of Official Analytical Chemists (AOAC). 1999. Official method of analysis. AOAC, Washington, DC.

Baldisserotto, B. \& Radünz, N. 2005. Jundiá (Rhamdia quelen). In: Baldisserotto, B. \& de Carvalho-Gomes, L. (Eds.). Espécies nativas para piscicultura no Brasil. Editora da Universidade Federal de Santa Maria, Santa Maria, pp. 303-319.

Bakke, A.M., Glover, C. \& Krogdahl, Å. 2010. Feeding, digestion, and absorption of nutrients. Fish Physiology, 30: 57-110.

Boscolo, W.R., Hayashi, C., Feiden, A., Meurer, F. \& Signor, A.A. 2008. Apparent energy digestibility and meal nutrients from tilapia filleting industrial waste for the Nile tilapia (Oreochromis niloticus L.). Ciência Rural, 38: 2579-2586. doi: 10.1590/S0103-8478200 8005000022
Bock, C.L., Pezzato, L.E., Cantelmo, O.A. \& Barros, M.M. 2007. Fitase em rações para tilápia-do-nilo na fase de crescimento. Revista Brasileira de Zootecnia, 36: 1455-1461. doi: 10.1590/S1516-35982007000700 001

Bureau, D.P., Harris, A.M. \& Cho, C.Y. 1999. Apparent digestibility of rendered animal protein ingredients for rainbow trout (Oncorhynchus mykiss). Aquaculture, 180: 345-358. doi: 10.1016/S0044-8486(99)00210-0

Bremer Neto, H., Graner, C.A.F., Pezzato, L.E., Padovani, C.P. \& Cantelmo, O.A. 2003. Diminuição do teor de óxido de crômio (III) usado como marcador externo. Revista Brasileira Zootecnia, 32: 249-255. doi: 10.1590/S1516-35982003000200001

De Miranda, E.C., Pezzato, A.C., Pezzato, L.E., Graner, C.F., Rosa, G.J. \& Pinto, L.G.Q. 2000. Relação calcio/fósforo disponível em rações para tilápia do Nilo (Oreochromis niloticus). Revista Brasileira de Zootecnia, 29: 2162-2171.

Diemer, O., Boscolo, W.R., Signor, A.A., Klein, S. \& Feiden, A. 2014. Fósforo na alimentação de pacus criados em tanques-rede. Arquivo Brasileiro de Medicina Veterinária e Zootecnia, 66: 1243-1250. doi: 10.1590/1678-5866

Food and Agriculture Organization (FAO). 2018. FishStat Plus - universal software for fishery statistical time series. [http://www.fao.org/fishery/statistics/software/ fishstat/en]. Reviewed: May 15, 2020.

Freitas, J.M.A.D., Sary, C., Luchesi, J.D., Feiden, A. \& Boscolo, W.R. 2011. Proteína e energia na dieta de jundiás criados em tanques-rede. Revista Brasileira de Zootecnia, 40: 2628-2633. doi: 10.1590/S1516-3598 2011001200002

Friesa, E.M., Oxford, J.H., Godoy, A.C., Hassamer, M.Z., Corrêia, A.F., Boscolo, W.R. \& Signor, A. 2020. Phytase on the digestibility of plant protein feed for silver catfish, Rhamdia voulezi. Aquaculture, 528: 735528. doi: 10.1016/j.aquaculture.2020.735528

Furuya, W.M., Pezzato, L.E., De Miranda, E.C., Furuya, V.R.B. \& Barros, M.M. 2008. Coeficientes de digestibilidade aparente da energia e nutrientes de alguns ingredientes pela tilápia-do-nilo, Oreochromis niloticus (L.) (linhagem tailandesa). Acta Scientiarum. Biological Sciences, 23: 465-469. doi: 10.4025/actascibiolsci.v23i0.2701

Guimarães, I.G., Pezzato, L.E., Barros, M.M. \& Fernandes, R.D.N. 2012. Apparent nutrient digestibility and mineral availability of protein-rich ingredients in extruded diets for Nile tilapia. Revista Brasileira de Zootecnia, 41: 1801-1808. doi: 10.1590/S1516-5982 012000800001

Kaushik, S.J. \& Seiliez, I. 2010. Protein and amino acid nutrition and metabolism in fish: current knowledge 
and future needs. Aquaculture Research, 41: 322-332. doi: 10.1111/j.1365-2109.2009.02174.x

Kitagima, R.E. \& Fracalossi, D.M. 2011. Digestibility of alternative protein-rich feedstuffs for channel catfish, Ictalurus punctatus. Journal of the World Aquaculture Society, 42: 306-312. doi: 10.1111/j.1749-7345.2011. 00468.x

Kumar, N., Krishnani, K.K., Kumar, P., Jha, A.K., Gupta, S.K. \& Singh, N.P. 2017. Dietary zinc promotes immuno-biochemical plasticity and protects fish against multiple stresses. Fish \& Shellfish Immunology, 62: 184-194. doi: 10.1016/j.fsi.2017.01.017

Kwong, R.W., Hamilton, C.D. \& Niyogi, S. 2013. Effects of elevated dietary iron on the gastrointestinal expression of Nramp genes and iron homeostasis in rainbow trout (Oncorhynchus mykiss). Fish Physiology and Biochemistry, 39: 363-372. doi: 10.1007/ s10695-012-9705-2

Lall, S.P. 2002. The vitamins. In: Hardy, R. (Ed.). Fish nutrition. Academic Press, Cambridge, pp. 61-141.

Lewandowski, V., Feiden, A., Signor, A., Bittencourt, F., Moro, E.B., Pessini, J.E. \& Boscolo, W.R. 2017. Digestibility of vegetal energetic ingredients supplemented with phytase for silver catfish (Rhamdia voulezi). Aquaculture, 467: 71-75. doi: 10.1016/j. aquaculture.2016.05.022

Liu, X.H., Ye, J.D., Wang, K., Kong, J.H., Yang, W. \& Zhou, L. 2012. Partial replacement of fish meal with peanut meal in practical diets for the Pacific white shrimp, Litopenaeus vannamei. Aquaculture Research, 43: 745-755. doi: 10.1111/j.1365-2109.2011.02883.x

Luo, Z., Zou, G.Y., Gao, Y., Ye, H.M., Xi, W.Q. \& Liu, X. 2017. Effect of dietary iron (Fe) levels on growth performance, hepatic lipid metabolism and antioxidant responses in juvenile yellow catfish Pelteobagrus fulvidraco. Aquaculture Nutrition, 23: 1475-1482. doi: 10.1111/anu.12523

Maffezzolli, G. \& De Oliveira-Nuñer, A.P. 2006. Crescimento de alevinos de jundiá, Rhamdia quelen (Pisces, Pimelodidae), em diferentes concentrações de oxigênio dissolvido. Acta Scientiarum. Biological Sciences, 28: 41-45. doi: 10.4025/actascibiolsci.v28i1. 1057

Moritz, J.S. \& Latshaw, J.D. 2001. Indicators of nutritional value of hydrolyzed feather meal. Poultry Science, 80: 79-86. doi: 10.1093/ps/80.1.79

National Research Council (NRC). 1993 Nutrient requirements of fish. National Academy Press, Washington, DC.

National Research Council (NRC). 2011. Nutrient requirements of fish and shrimp. The National Academies Press, Washington, DC.

Nwanna, L.C., Adebayo, I.A. \& Omitoyin, B. 2009. Effect of graded levels of phosphorus on growth and mineral concentration in giant African catfish Heterobranchus bidorsalis. African Journal of Biotechnology, 8: 39473953.

Oliveira-Filho, P.R. \& Fracalossi, D.M. 2006. Coeficientes de digestibilidade aparente de ingredientes para juvenis de jundiá. Brazilian Journal of Animal Science, 35: 1581-1587. doi: 10.1590/S1516-3598200 6000600002

Pastore, S.C., Gaiotto, J.R., Ribeiro, F.A.S. \& Nunes, A.J.P. 2013. Formulação de rações e boas práticas de fabricação. In: Machado, D. \& Cyrino, J.E.P. (Eds.). Nutriaqua. Aquabio, Santa Catarina, pp. 293-346.

Pedron, F.A., Neto, J.R., Emanuelli, T., Da Silva, L.P., Lazzari, R., Corrêia, V. \& Veiverberg, C.A. 2008. Cultivo de jundiás alimentados com dietas com casca de soja ou de algodão. Pesquisa Agropecuária Brasileira, 43: 93-98. doi: 10.1590/S0100-204X200 8000100012

Pezzato, L.E., Miranda, E.C.D., Barros, M.M., Pinto, L.G.Q., Furuya, W.M. \& Pezzato, A.C. 2002. Digestibilidade aparente de ingredientes pela tilápia do Nilo (Oreochromis niloticus). Revista Brasileira de Zootecnia, 31: 1595-1604. doi: 10.1590/S1516-59820 02000700001

Piedras, S., Moraes, P. \& Pouey, J. 2018. Crescimento de juvenis de jundiá (Rhamdia quelen), de acordo com a temperatura da água. Boletim do Instituto de Pesca, 30 : 177-182.

Radunz-Neto, J.R. \& De Borda, M.R. 2013. Exigências nutricionais e alimentação do jundiá. In: Machado, D. \& Cyrino, J.E.P. (Eds.). Nutriaqua. Aquabio, Santa Catarina, pp. 241-254.

Rodehutscord, M., Gregus, Z. \& Pfeffer, E. 2000. Effect of phosphorus intake on faecal and non-faecal phosphorus excretion in Rainbow trout (Oncorhynchus mykiss) and the consequences for comparative phosphorus availability studies. Aquaculture. 188: 383-398. doi: 10.1016/S0044-8486(00)00341-0

Schamber, C.R., Boscolo, W.R., Natali, M.R.M., Michelato, M., Furuya, V.R.B. \& Furuya, W.M. 2014. Growth performance and bone mineralization of large Nile tilapia (Oreochromis niloticus) fed graded levels of available phosphorus. Aquaculture International, 22: 1711-1721. doi: 10.1007/s10499-014-9776-4

Signor, A., Lewandowski, V., Silva, R.A.D., Fries, E.M. \& Schuller, J.M. 2016. Effect of phytase on digestibility of corn, sorghum and wheat bran by silver catfish (Rhamdia voulezi). Acta Scientiarum. Animal Sciences, 38: 355-359. doi: 10.4025/actascianimsci. v38i4.32054

Silva, T.S.C., Moro, G.V., Silva, T.B.A., Dairiki, J.K. \& Cyrino, J.E.P. 2013. Digestibility of feed ingredients for the striped surubim Pseudoplatystoma reticulatum. 
Aquaculture Nutrition, 19: 491-498. doi: 10.1111/ anu. 12000

Suttle, N.F. 2010. Mineral nutrition of livestock. MPG Books Group, London.

Sugiura, S.H., Dong, F.M. \& Hardy, R.W. 1998a. Effects of dietary supplements on the availability of minerals in fish meal; preliminary observations. Aquaculture, 160: 283-303. doi: 10.1016/S0044-8486(97)00302-5

Sugiura, S.H., Roy, P.K. \& Ferraris, R.P. 2006. Dietary acidification enhances phosphorus digestibility but decreases $\mathrm{H}^{+} / \mathrm{K}^{+}$-ATPase expression in rainbow trout. Journal of Experimental Biology, 209: 3719-3728. doi: $10.1242 /$ jeb.02436

Received: 26 October 2020; Accepted: 11 April 2021
Sugiura, S.H., Dong, F.M., Rathbone, C.K. \& Hardy, R.W. 1998b. Apparent protein digestibility and mineral availabilities in various feed ingredients for salmonid feeds. Aquaculture, 159: 177-202. doi: 10.1016/S0044-8486(97)00177-4

Zhang, H., Yi, L., Sun, R., Zhou, H., Xu, W., Zhang, W. \& Mai, K. 2016. Effects of dietary citric acid on growth performance, mineral status and intestinal digestive enzyme activities of large yellow croaker Larimichthys crocea (Richardson, 1846) fed high plant protein diets. Aquaculture, 453: 147-153. doi: 10.1016/j.aquaculture.2015.11.032 